\title{
PENINGKATAN HASIL BELAJAR DAN MOTIVASI MELALUI PENERAPAN MODEL DISCOVERY LEARNING BERBANTUAN MULTIMEDIA PADA MATERI JUJUR, AMANAH, DAN ISTIQAMAH
}

\author{
Hanri Eko Saputro \\ Teacher of Junior High School 2 Rembang Central Java, Indonesian. \\ Padaran, Kec. Rembang, Rembang Regency, Jawa Tengah 59219 \\ E-mail: hanriekosaputro@yahoo.com
}

\begin{abstract}
Islamic education learning outcomes and optimal character will be the main capital in everyday life. On the other hand the presentation of learning Islamic education and Budi Character assessed tend to be indoktrinatif and not significantly so that the learning is very low. This is evident from the results of the average value of the ability of knowledge of students in the material honest, trustful, Istiqamah only 72.31, completeness percentage of $37.5 \%$, from the observations of the percentage of students who are actively involved in the learning of only $40.63 \%$. This study aims to improve learning outcomes and motivation of students in the material by using multimedia-aided model of Discovery Learning. Of the two cycles are performed in this study showed that the average ability of knowledge of learners into 78.78 in the first cycle and increased again to 84.91 in the second cycle. While the percentage of completeness of learners increased to $68.75 \%$ in the first cycle and increased again to $87.5 \%$ in the second cycle. Percentage of active participation of students also increased to $46.86 \%$ in the first cycle and increased to $84.38 \%$ in the second cycle.
\end{abstract}

Keywords : Learning Outcomes, Motivations, Discovery Learning, Multimedia

\begin{abstract}
Abstrak
Hasil belajar pendidikan agama Islam dan mengoptimalkan pendidikan karakter akan menjadi modal utama dalam kehidupan sehari-hari. Pada sisi lain presentasi pembelajaran pendidikan Agama Islam karakter Budi Pekerti dinilai cenderung indoktrinatif dan tidak signifikan, sehingga pembelajaran sangat rendah. Hal ini terbukti dari hasil nilai rata-rata kemampuan pengetahuan siswa dalam penyelesaian materi tentang jujur, amanah, dan istiqamah memperoleh 72.31, persentase kelengkapan $37.5 \%$, dari pengamatan persentase siswa yang terlibat secara aktif dalam pembelajaran hanya 40, 63\%. Model penelitian ini bertujuan untuk meningkatkan hasil belajar dan motivasi siswa dalam materi jujur, amanah, dan istiqamah dengan menggunakan multimedia dibantu dengan discovery learning. Dari dua siklus yang dilakukan dalam penelitian ini menunjukkan bahwa kemampuan rata-rata pengetahuan peserta didik menjadi 78.78 pada siklus I (pertama) dan meningkat lagi menjadi 84.91 pada siklus II (kedua). Sementara persentase kelengkapan peserta didik meningkat menjadi $68.75 \%$ pada siklus I dan meningkat lagi menjadi 87.5 pada siklus II.
\end{abstract}

Kata Kunci: Hasil belajar, motivasi, discovery learning, multimedia. 
FITRAH Vol.01 No. 2 Juli-Desember 2015

\section{PENDAHULUAN}

Pembaharuan pendidikan di segala lini mulai tergugah pada saat sering terjadi proses ekspose ratifikasi tingkat kesuksesan hasil belajar melalui kinerja output pendidikan dalam kancah persaingan dunia kerja baik tingkat nasional maupun internasional. Banyak media menyoroti dan mengkritik kualitas pendidikan Indonesia yang dianggap masih rendah. Untuk mensikapi kritikan tersebut, pemerintah melakukan berbagai perubahan dalam kurikulum pendidikan yang diharapkan mampu meningkatkan kualitas pendidikan Indonesia.

Hal ini dilakukan demi peningkatan sumber daya manusia Indonesia pada masa mendatang sehingga siap bersaing dengan siapapun, dimanapun dan kapanpun. Sumber daya manusia yang kuat tidak akan bernilai tanpa adanya keimanan dan ketakwaan, yang salah satunya dapat dikembangkan melalui pembelajaran Pendidikan Agama Islam (PAI) di sekolah.

Sekolah sebagai wahana formal dituntut untuk dapat menciptakan suasana dan proses pembelajaran yang kondusif sehingga potensi peserta didik berkembang optimal dan seutuhnya. ${ }^{1}$ Dengan demikian, pengembangan potensi untuk menjadi manusia bermartabat, beriman dan bertakwa kepada Allah SWT, berbudi pekerti luhur (akhlak mulia) dan memiliki kemampuan untuk memikul tanggung jawab sebagai individu dan anggota masyarakat dapat terwujud. ${ }^{2}$

Hal ini salah satunya dapat diwujudkan jika terjadi keberhasilan dalam kegiatan pembelajaran yang tentunya juga sangat dipengaruhi oleh kondisi yang terjadi selama kegiatan pembelajaran berlangsung. Kondisi pembelajaran yang kondusif akan menjadikan proses pembelajaran berlangsung secara efektif dan efisien. Selain itu, motivasi belajar yang tinggi juga menjadi salah satu syarat kuat dalam mendukungnya. Teori belajar apa pun apabila didukung oleh motivasi belajar yang tinggi dalam proses pembelajaran, maka akan memperoleh hasil yang maksimal.

Al-Qur'an sebagai sumber pedoman hidup dan hukum Islam telah memerintahkan untuk memilih metode yang tepat dalam proses pembelajaran, seperti yang terdapat dalam surat an-Nahl ayat 125 yang artinya: "Serulah (manusia) kepada jalan Tuhanmu dengan hikmah dan pengajaran yang baik, dan berdebatlah dengan mereka dengan cara yang baik. Sesungguhnya Tuhanmu, Dialah yang lebih mengetahui siapa yang sesat dari jalan-Nya dan Dialah yang lebih mengetahui siapa yang mendapat petunjuk."

Mata pelajaran Pendidikan Agama Islam dan Budi Pekerti di SMP di antaranya

${ }^{1}$ Achmadi, Ideologi Pendidikan Islam: Paradigma Humanisme Teosentris, (Yogyakarta: Pustaka Pelajar, 2005), hlm. 113.

2 Achmadi, Dekonstruksi Pendidikan Islam Sebagai Subsistem Pendidikan Nasional, dalam Guru Besar Bicara: Mengembangkan Keilmuan Pendidikan Islam. (Semarang: RaSAIL Media Group, 2010), hlm. 122. 
bertujuan untuk mendidik para peserta didik agar mempunyai akhlak mulia serta mampu mengaplikasikannya dalam setiap segi kehidupan. Hal ini didukung dengan adanya pembaharuan pada kurikulum 2013 yang menyeimbangkan aspek sikap, keterampilan, dan pengetahuan secara terpadu. Adanya keseimbangan antara tiga aspek tersebut, diharapkan peserta didik tidak hanya mampu memahami materi pembelajaran tetapi juga mampu dan terampil menerapkannya dalam kehidupan sehari-hari.

Materi pokok jujur, amanah, dan istiqamah yang dibahas dalam mata pelajaran Pendidikan Agama Islam dan Budi Pekerti kelas VII Semester 1 Kurikulum 2013 perlu mendapat perhatian khusus karena berkaitan dengan pembentukan akhlak yang mulia. Namun demikian, proses pembelajaran PAI yang selama ini berlangsung cenderung mengarah pada penekanan aspek pengetahuan dengan menggunakan pendekatan ceramah. Materi ini seringkali diberikan pada peserta didik dalam bentuk doktrin-doktrin yang harus diterima peserta didik sebagai hasil jadi. Hal ini menyebabkan peserta didik menjadi kurang termotivasi dalam mengikuti pembelajaran yang tentu berefek pada rendahnya pemahaman terhadap materi yang dipelajari dan pengamalannya dalam kehidupan sehari-hari.

Selain itu, peserta didik juga belum dapat aktif dalam kegiatan pembelajaran karena kurang diberikan stimulus yang mengkondisikan peserta didik untuk mengkomunikasikan materi yang belum dipahami. Pembelajaran searah yang terpusat pada guru menyebabkan peserta didik kurang kritis dalam bertanya atau mengungkapkan pendapat karena tidak adanya fasilitas untuk itu.

Hasil belajar peserta didik dengan pendekatan ceramah dan pemberian tugas berupa soal-soal latihan yang ada di LKS ternyata masih rendah, yaitu rata-ratanya hanya 72,31 dan persentase ketuntasan hanya 37,5\%. Sedangkan berdasarkan hasil pengamatan, persentase peserta didik yang terlibat aktif dalam kegiatan pembelajaran hanya 40,63\%.

Hal ini menjadi masalah yang serius karena dikhawatirkan materi Jujur, Amanah, dan Istiqamah hanya terlewati begitu saja, tanpa kesan, tidak bermakna, dan tidak mendapatkan hasil belajar yang optimal. Sebagaimana diketahui, materi Jujur, Amanah, dan Istiqamah memegang peranan yang cukup penting karena materi ini menjadi salah satu landasan pokok dalam kehidupan sehari-hari.

Berdasarkan latar belakang tersebut, peneliti melakukan perubahan pembelajaran pada materi Jujur, Amanah, dan Istiqamah melalui model Discovery Learning berbantuan multimedia. Kegiatan diskusi dalam model pembelajaran ini memberikan peluang yang sangat besar kepada peserta didik untuk berbicara, berpendapat, dan berkomunikasi. Hal ini memberi kesempatan anak didik untuk mengolah informasi dan mengkomunikasikannya selama kegiatan pembelajaran sehingga pemahaman peserta didik dapat meningkat. Multimedia yang digunakan dalam penelitian ini berupa media powerpoint dan flipbook. Media ini diharapkan dapat meningkatkan motivasi peserta didik sehingga dapat lebih 
FITRAH Vol.01 No. 2 Juli-Desember 2015

mudah dalam belajar dan hasil belajar pun menjadi optimal.

\section{LANDASAN TEORI}

\section{Hasil Belajar}

Sudjana menyatakan bahwa belajar merupakan proses yang ditandai dengan adanya perubahan-perubahan pada diri seseorang. Perubahan sebagai hasil dari proses belajar dapat ditunjukkan dalam berbagai bentuk seperti perubahan pengetahuan, pemahaman, sikap dan tingkah laku, keterampilan, kecakapan, kebiasaan, dan perubahan aspek-aspek lain yang ada pada individu yang belajar. Sedangkan hasil belajar diperoleh individu melalui latihan dan pengalaman. ${ }^{3}$ Belajar dapat diartikan sebagai perubahan tingkah laku pada diri individu berkat adanya interaksi antara individu dengan individu dan individu dengan lingkungannya sehingga mereka mampu berinteraksi dengan lingkungannya. ${ }^{4}$

Hasil belajar merupakan perubahan-perubahan perilaku akibat interaksi individu dengan lingkungan. ${ }^{5}$ Proses perubahan perilaku yang sengaja direncanakan agar terjadi perubahan perlaku ini disebut dengan proses belajar. Proses ini merupakan suatu aktivitas psikis/mental yang berlangsung dalam interaksi aktif dengan lingkungan yang menghasilkan perubahan-perubahan yang relatif konstan dan berbekas.

Sedangkan hasil pembelajaran juga dapat diperoleh dari kerja sama dengan orang lain. Hasil belajar dapat diperoleh melalui sharing antara teman. Guru juga dapat merancang strategi pembelajaran melalui kelompok, baik kelompok besar maupun kecil. Merancang pembelajaran PAI yang melibatkan kelompok menjadikan peserta didik mampu berkomunikasi dengan sesama temannya untuk saling bertanya, mencari menemukan jawaban, membangun pengetahuan, keterampilan dan nilai-nilai seperti nilai kebersamaan. ${ }^{6}$

\section{Motivasi Belajar}

Menurut pendapat Sartain sebagaimana disitir oleh Purwanto, motivasi adalah suatu pernyataan yang kompleks di dalam suatu organisme yang mengarahkan tingkah laku terhadap suatu tujuan (goal) atau perangsang (incentive). ${ }^{7}$ Tujuan (goal) adalah yang menentukan atau membatasi tingkah laku organisme itu. Jika yang ditekankan adalah fakta atau objeknya, yang menarik organisme itu, maka dipergunakan istilah perangsang

\footnotetext{
${ }^{3}$ Nana Sudjana, Cara Belajar Siswa Aktif Dalam Belajar Mengajar, (Bandung: Sinar Baru, 2000), hlm. 5.

${ }^{4}$ Uzer Usman, Upaya Optimalisasi kegiatan Belajar Mengajar, (Bandung: Remaja Rosdakarya, 1993), hlm. 4.

${ }^{5}$ Suprayekti, Interaksi Belajar Mengajar, (Jakarta: Depdiknas, 2003), hlm. 4.

${ }^{6}$ Nurhadi, Pembelajaran Kontekstual, (Malang: Universitas Negeri Malang, 2004), hlm. 47.

${ }^{7}$ Ngalim Purwanto, Psikologi Pendidikan, (Bandung: Remaja Rosdakarya, 2002), hlm. 61.
} 
(incentive). Lebih lanjut Purwanto mendefinisikan motivasi dalam tiga kelompok, yaitu menggerakkan, mengarahkan dan menopang tingkah laku manusia. ${ }^{8}$

Suryabrata mengatakan bahwa motif adalah keadaan dalam pribadi orang yang mendorong individu untuk melakukan aktivitas-aktivitas tertentu guna mencapai sesuatu tujuan. ${ }^{9}$

Dari pengertian di atas kiranya jelas bahwa motivasi adalah suatu usaha yang disadari untuk menggerakkan, mengarahkan dan menjaga tingkah laku manusia agar ia terdorong untuk bertindak melakukan sesuatu sehingga mencapai hasil atau tujuan tertentu. Apabila dikaitkan dengan belajar, motivasi ini diarahkan untuk mencapai hasil atau tujuan belajar dengan cara siswa bertindak secara nyata dalam proses pembelajaran. Sedangkan guru merupakan orang terdekat bagi anak saat di sekolah sehingga mereka paling berperan untuk memotivasi anak dalam masalah belajar selama di sekolah.

\section{Model Pembelajaran Discovery Learning}

Discovery mempunyai prinsip yang sama dengan inkuiri dan Problem Solving. Tidak ada perbedaan yang prinsipil pada ketiga istilah ini. Discovery Learning lebih menekankan pada ditemukannya konsep atau prinsip yang sebelumnya tidak diketahui. Masalah yang dihadapkan kepada siswa semacam masalah yang direkayasa oleh guru.

Adapun pada inkuiri masalahnya bukan hasil rekayasa, sehingga siswa harus mengerahkan seluruh pikiran dan keterampilannya untuk mendapatkan temuan-temuan di dalam masalah itu melalui proses penelitian, sedangkan Problem Solving lebih memberi tekanan pada kemampuan menyelesaikan masalah. Pada Discovery Learning materi tidak disampaikan dalam bentuk final akan tetapi siswa didorong untuk mengidentifikasi yang ingin diketahui dilanjutkan dengan mencari informasi sendiri kemudian mengorgansasi atau membentuk (konstruktif) apa yang mereka ketahui dan mereka pahami dalam suatu bentuk akhir.

Dalam Discovery Learning bahan ajar tidak disajikan dalam bentuk akhir, siswa dituntut untuk melakukan berbagai kegiatan menghimpun informasi, membandingkan, mengkategorikan, menganalisis, mengintegrasikan, mereorganisasikan bahan dan membuat kesimpulan-kesimpulan. Bruner mengatakan bahwa proses belajar akan berjalan dengan baik dan kreatif jika guru memberikan kesempatan kepada siswa untuk menemukan suatu konsep, teori, aturan, atau pemahaman melalui contoh-contoh yang ia jumpai dalam kehidupannya. ${ }^{10}$

Langkah-langkah dalam mengaplikasikan model discovery learning di kelas adalah sebagai berikut.

\footnotetext{
8 Ibid, hlm. 72

${ }^{9}$ Sumadi Suryabrata, Psikologi Pendidikan, (Jakarta: RajaGrafindo Persada, 2002), hlm. 70.

${ }^{10}$ Asri Budiningsih, Belajar dan Pembelajaran, (Jakarta: Rineka Cipta, 2004), hlm. 41.
} 
FITRAH Vol.01 No. 2 Juli-Desember 2015

\section{1) Perencanaan}

Perencanaan pada model ini meliputi hal-hal sebagai berikut.

a. Menentukan tujuan pembelajaran.

b. Melakukan identifikasi karakteristik siswa (kemampuan awal, minat, gaya belajar, dan sebagainya).

c. Memilih materi pelajaran.

d. Menentukan topik-topik yang harus dipelajari siswa secara induktif (dari contohcontoh generalisasi).

e. Mengembangkan bahan-bahan belajar yang berupa contoh-contoh, ilustrasi, tugas dan sebagainya untuk dipelajari siswa.

f. Mengatur topik pelajaran dari yang sederhana ke kompleks, dari yang konkret ke abstrak, atau dari tahap enaktif, ikonik sampai ke simbolik.

g. Melakukan penilaian proses dan hasil belajar siswa.

2) Pelaksanaan

Menurut Muhibbin Syah, beberapa prosedur yang harus dilaksanakan dalam mengaplikasikan metode Discovery Learning adalah sebagai berikut. ${ }^{11}$

a) Stimulation (stimulasi/pemberian rangsangan)

Guru memulai kegiatan pembelajaran dengan mengajukan pertanyaan, anjuran membaca buku, dan aktivitas belajar lainnya yang mengarah pada persiapan pemecahan masalah.

b) Problem statement (pernyataan/ identifikasi masalah)

Siswa mengidentifikasi sebanyak mungkin masalah yang relevan dengan bahan pelajaran, kemudian salah satunya dipilih dan dirumuskan dalam bentuk hipotesis (jawaban sementara atas pertanyaan masalah).

c) Data collection (pengumpulan data)

Ketika siswa melakukan eksperimen atau eksplorasi, siswa mengumpulkan informasi yang relevan sebanyak-banyaknya untuk membuktikan benar atau tidaknya hipotesis. Data dapat diperoleh melalui membaca literatur, mengamati objek, wawancara dengan narasumber, melakukan uji coba sendiri dan sebagainya.

d) Data processing (pengolahan data)

Pengolahan data merupakan kegiatan mengolah data dan informasi yang telah diperoleh para siswa baik melalui wawancara, observasi, dan sebagainya, lalu ditafsirkan.

e) Verification (pembuktian)

${ }^{11}$ Muhibbin Syah, Psikologi Belajar, (Bandung: Remaja Rosdakarya, 2007), hlm. 243. 
Pada tahap ini siswa melaksanakan pemeriksaan secara cermat untuk membuktikan benar atau tidaknya hipotesis yang telah ditetapkan, dihubungkan dengan hasil pengolahan data.

f) Generalization (menarik kesimpulan/generalisasi)

Tahap generalisasi/menarik kesimpulan adalah proses menarik kesimpulan yang dapat dijadikan prinsip umum dan berlaku untuk semua kejadian atau masalah yang sama, dengan memperhatikan hasil verifikasi. Berdasarkan hasil verifikasi maka dirumuskan prinsip-prinsip yang mendasari generalisasi.

\section{Multimedia}

Rossi dan Breidle mengemukakan bahwa media pembelajaran adalah seluruh alat dan bahan yang dapat dipakai untuk mencapai tujuan pendidikan seperti radio, televisi, buku, koran, majalah dan sebagainya. ${ }^{12}$

Multimedia merupakan perpaduan antara berbagai media (format file) yang berupa teks, gambar (vektor atau bitmap), grafik, sound, animasi, video, interaksi, dll. yang telah dikemas menjadi file digital (komputerisasi), digunakan untuk menyampaikan pesan kepada publik. Jadi, multimedia interaktif, yaitu media pembelajaran yang merupakan perpaduan antara berbagai media (format file) yang berupa teks, gambar (vektor atau bitmap), grafik, sound, animasi, video, interaksi, dan lain-lainl yang telah dikemas menjadi file digital (komputerisasi), digunakan untuk menyampaikan pesan kepada siswa.

Multimedia interaktif dapat mengatasi sikap pasif dari siswa, menimbulkan kegairahan belajar, memungkinkan interaksi langsung antara siswa dengan dengan lingkungan dan kenyataan, serta memungkinkan siswa belajar secara mandiri.

\section{Kerangka Berpikir Penelitian}

Kerangka berpikir dalam penelitian ini adalah sebagai berikut.

Sebelum dilakukan tindakan, pembelajaran materi Jujur, Amanah, dan Istiqamah dilakukan dengan pendekatan ceramah kemudian siswa mengerjakan soal-soal latihan di LKS. Selanjutnya dilakukan tes tentang materi ini dan menghasilkan nilai rata-rata 72,31 dengan persentase ketuntasan hanya 37,5\%. Adapun menurut hasil pengamatan, persentase siswa yang terlibat aktif dalam kegiatan pembelajaran adalah 40,63\%.

Guru kemudian melakukan tindakan yang terdiri atas 2 siklus sebagai berikut.

1. Pada siklus I guru melakukan pembelajaran materi Jujur, Amanah, dan Istiqamah dengan menggunakan model pembelajaran Discovery Learning. Pada proses

12 Wina Sanjaya, Strategi Pembelajaran Berorientasi Standar Proses Pendidikan, (Jakarta: Kencana, 2008), hlm. 163. 
FITRAH Vol.01 No. 2 Juli-Desember 2015

pembelajaran siklus I ini, siswa diharapkan terlibat aktif dalam pembelajaran serta termotivasi untuk mengikuti kegiatan pembelajaran sehingga hasil belajar meningkat.

2. Pada siklus II guru melakukan pembelajaran materi Jujur, Amanah, dan Istiqamah dengan menggunakan model pembelajaran Discovery Learning berbantuan multimedia. Proses pembelajaran pada siklus II ini bertujuan agar siswa terlibat lebih aktif dalam pembelajaran, lebih termotivasi untuk mengikuti kegiatan pembelajaran, dan hasil belajar pada materi Jujur, Amanah, dan Istiqamah bisa meningkat.

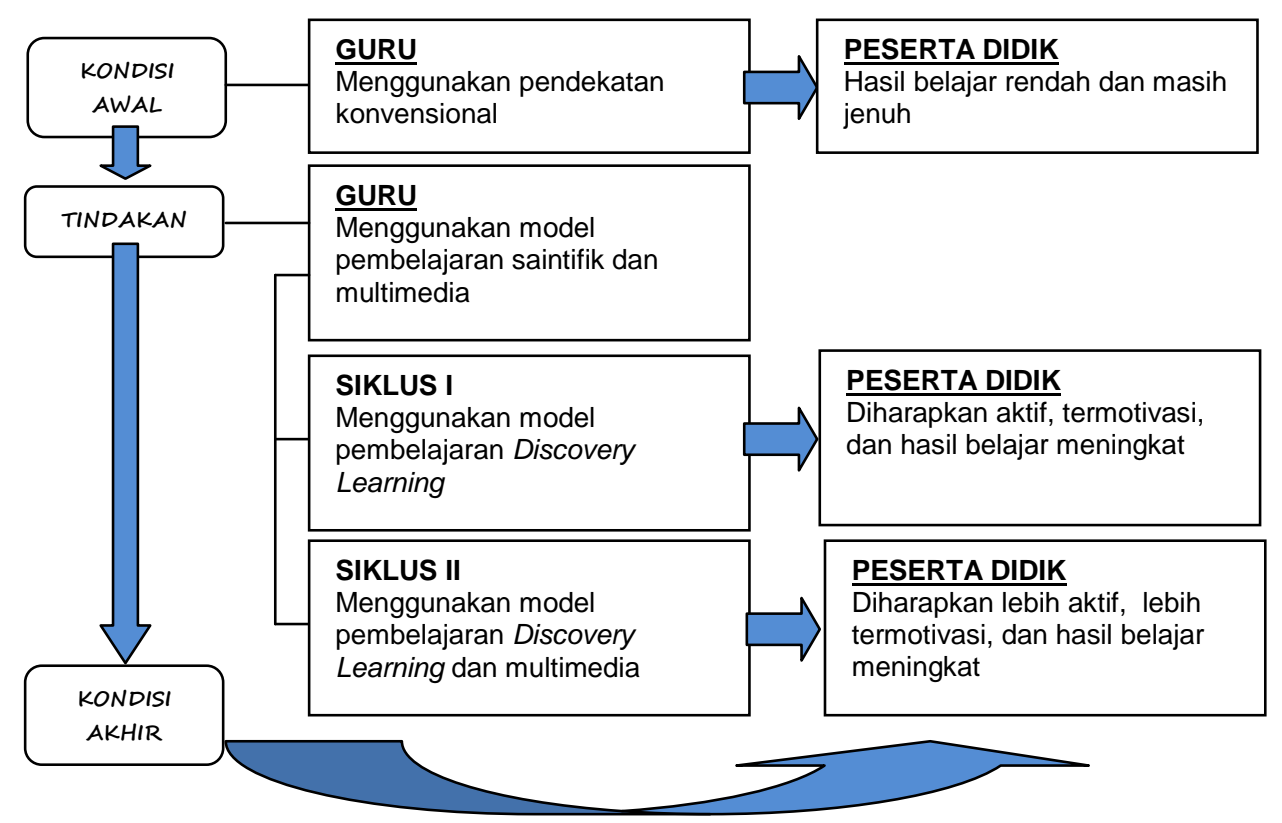

Gambar 1. Kerangka Berpikir Penelitian

\section{METODE PENELITIAN}

Penelitian ini dilakukan pada bulan Juli sampai November 2014 dan bertempat di SMP Negeri 2 Rembang, dengan subjek penelitian siswa kelas VII.3 sejumlah 32 orang. Data dalam penelitian ini diperoleh melalui tes pengetahuan, pengamatan (observasi), dan wawancara. Tes pengetahuan digunakan untuk mengukur pemahaman siswa tentang materi Jujur, Amanah, dan Istiqamah. Observasi dilakukan peneliti untuk mengetahui keaktifan siswa dalam mengikuti proses pembelajaran PAI dan Budi Pekerti pada materi Jujur, Amanah, dan Istiqamah. Sedangkan wawancara dilakukan oleh peneliti untuk mengetahui tingkat motivasi siswa terhadap pembelajaran pada materi Jujur, Amanah, dan Istiqamah.

Alat pengumpul data yang digunakan dalam penelitian ini berupa Butir Soal Tes, Lembar Observasi, dan Pedoman Wawancara. Validasi data dilakukan dengan teknik trianggulasi. Trianggulasi dilakukan untuk membuktikan apakah hasil pengamatan yang diperoleh tentang hasil belajar dan motivasi siswa pada materi Jujur, Amanah, dan 
Istiqamah, sesuai dengan apa yang sesungguhnya dalam kenyataan, serta apakah penjelasan yang diberikan informan memang sesuai dengan keadaan sebenarnya.

Adapun untuk analisis data yang dilaksanakan dalam penelitian ini adalah sebagai berikut.

1. Hasil tes pengetahuan dibuat rata-rata dan dianalisis secara deskriptif. Hasil tes juga dianalisis untuk mengetahui persentase siswa yang mencapai batas ketuntasan/ Kriteria Ketuntasan Minimal (KKM).

2. Hasil pengamatan atau observasi peneliti dianalisis secara deskriptif tentang berbagai kejadian dalam proses pembelajaran.

a. Dinyatakan sangat aktif jika $81-100 \%$ siswa berpartisipasi aktif dalam pembelajaran.

b. Dinyatakan aktif jika $61-80 \%$ siswa berpartisipasi aktif dalam pembelajaran.

c. Dinyatakan cukup aktif jika $41-60 \%$ siswa berpartisipasi aktif dalam pembelajaran.

d. Dinyatakan kurang aktif jika terdapat kurang dari $21-40 \%$ siswa yang terlibat aktif dalam pembelajaran.

e. Dinyatakan tidak aktif jika hanya terdapat $1-20 \%$ siswa yang terlibat aktif dalam pembelajaran.

3. Hasil wawancara dianalisis secara deskripsi.

a. Dinyatakan sangat menarik jika lebih dari 50\% siswa menyatakan sangat tertarik.

b. Dinyatakan cukup menarik jika lebih dari 50\% siswa menyatakan cukup tertarik.

c. Dinyatakan kurang menarik jika lebih dari 50\% siswa menyatakan kurang tertarik.

d. Dinyatakan tidak menarik jika lebih dari 50\% siswa menyatakan tidak tertarik.

Indikator kinerja dari penelitian ini adalah sebagai berikut.

1. Terjadi peningkatan rata-rata nilai pengetahuan materi Jujur, Amanah, dan Istiqamah sehingga nilai rata-ratanya lebih dari 80.

2. Persentase siswa yang mencapai ketuntasan belajar dapat mencapai $\geq 85 \%$.

3. Persentase siswa yang terlibat aktif dalam kegiatan pembelajaran mencapai $\geq 80 \%$.

4. Hasil wawancara, lebih dari 50\% menyatakan sangat tertarik terhadap pembelajaran Jujur, Amanah, dan Istiqamah melalui model pembelajaran berbasis saintifik berbantuan multimedia.

Penelitian ini menggunakan dua siklus. Langkah-langkah dalam tiap siklus terdiri atas:

1. Perencanaan/persiapan (Planning)

2. Tindakan (Acting)

3. Pengamatan (Observing)

4. Refleksi. 
FITRAH Vol.01 No. 2 Juli-Desember 2015

Adapun penjelasan tentang langkah-langkah tersebut adalah sebagai berikut.

1. Perencanaan/persiapan (Planning)

Pada tahap perencanaan, peneliti melakukan beberapa kegiatan seperti mencari referensi yang berkaitan dengan materi Jujur, Amanah, dan Istiqamah, model pembelajaran berbasis saintifik, dan media pembelajaran, dan eksplorasi pengalaman. Referensi tersebut diperoleh peneliti dari buku-buku yang relevan maupun dari internet.

Pada tahapan ini peneliti juga melakukan kegiatan-kegiatan berikut.

a. Pembuatan jadwal penelitian

b. Pembuatan Rencana Pelaksanaan Pembelajaran (RPP)

c. Pencarian bahan pembelajaran terkait materi Jujur, Amanah, dan Istiqamah.

d. Pembuatan lembar kegiatan siswa yang berisi tugas dan kegiatan siswa. Lembar tugas ini diharapkan mampu mengarahkan fokus perhatian siswa terhadap kegiatan pembelajaran.

e. Mempersiapkan media pembelajaran tentang materi Jujur, Amanah, dan Istiqamah berupa power point dan flipbook.

f. Pembuatan instrumen penilaian.

g. Pembuatan lembar pengamatan.

h. Pembuatan daftar pertanyaan untuk wawancara.

2. Tindakan (Acting)

Tindakan penelitian dilakukan untuk meningkatkan hasil belajar dan motivasi siswa pada materi Jujur, Amanah, dan Istiqamah. Kegiatan ini dilakukan di ruang kelas dengan model pembelajaran berbasis saintifik berbantuan multimedia.

3. Observasi

Obervasi atau pengamatan dilakukan untuk mengetahui perkembangan kemampuan siswa. Kegiatan ini dilakukan di setiap siklus. Dalam tahap ini yang diamati antara lain :

a. Jalannya proses pembelajaran.

b. Situasi lingkungan dan subjek penelitian pada waktu proses pembelajaran.

c. Tingkah laku siswa selama proses pembelajaran berlangsung.

4. Refleksi

Kegiatan refleksi dilakukan setiap akhir siklus. Hal ini dilakukan untuk mengetahui kekurangan, kelemahan, dan kelebihan kegiatan pembelajaran selama penelitian. Setelah mengetahui keberhasilan dan kendala yang dialami dalam pelaksanaan pembelajaran pada siklus I, peneliti melakukan penyempurnaan tindakan, modifikasi, dan inovasi pada siklus berikutnya. Peneliti berusaha agar hasil belajar materi tentang Jujur, Amanah, dan Istiqamah sampai pada hasil yang optimal.

Prosedur penelitian ini secara sederhana dapat digambarkan melalui bagan berikut ini. 


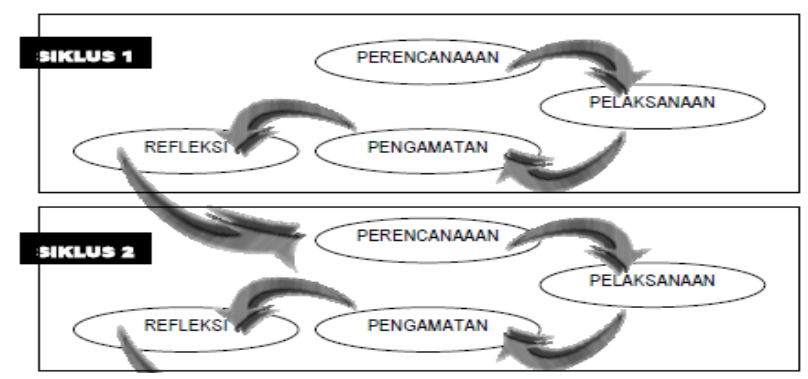

Gambar 2 : Langkah-langkah Penelitian Tindakan Kelas

\section{HASIL PENELITIAN DAN PEMBAHASAN}

\section{Deskripsi Kondisi Awal}

Pada awalnya peneliti melaksanakan pembelajaran materi Jujur, Amanah, dan Istiqamah dengan menggunakan pendekatan ceramah dalam kelas. Setelah pembelajaran selesai, peneliti melakukan penilaian pengetahuan serta melakukan pengamatan terhadap aktivitas siswa. Hasil penilaian dan observasi tersebut tergambar dalam tabel di berikut ini.

\begin{tabular}{|c|c|c|c|}
\hline $\begin{array}{c}\text { Indikator } \\
\text { Kemampuan }\end{array}$ & Rata-rata & $\begin{array}{c}\text { Persentase siswa } \\
\text { yang tuntas }\end{array}$ & $\begin{array}{c}\text { Persentase partisipasi siswa } \\
\text { dalam pembelajaran }\end{array}$ \\
\hline $\begin{array}{l}\text { Kemampuan } \\
\text { Pengetahuan }\end{array}$ & 72,31 & $37,5 \%$ & $40,63 \%$ \\
\hline KKM & 80 & 80 & \\
\hline
\end{tabular}

Tabel 1. Hasil penilaian dan pengamatan pada kondisi awal

Berdasarkan tabel 1 tersebut, dapat dinyatakan bahwa partisipasi keaktifan siswa dalam mengikuti pembelajaran PAI materi Jujur, Amanah, dan Istiqamah dengan pendekatan ceramah sangat rendah. Rendahnya partisipasi tersebut menyebabkan hasil belajar rendah.

Pada saat dilakukan tes kemampuan pengetahuan tentang materi Jujur, Amanah, dan Istiqamah hanya terdapat 37,5\% siswa yang tuntas dan $62,5 \%$ yang belum tuntas dan rata-rata nilainya 72,31 . Sementara hasil observasi dan wawancara menyatakan bahwa siswa tertarik dalam kegiatan pembelajaran yang dilakukan hanya 40, 63\%.

Hasil belajar yang demikian membuat peneliti berusaha untuk mencari solusi agar pembelajaran dapat lebih menarik dan mampu memancing perhatian siswa. Peneliti mempunyai ide untuk melaksanakan pembelajaran pada materi Jujur, Amanah, dan Istiqamah dengan model Discovery Learning.

\section{Deskripsi Tindakan Siklus I}

a. Perencanaan Tindakan

Pada tahap perencanaan peneliti melakukan beberapa kegiatan sebagai berikut. 
a. Pembuatan RPP (lesson plan) tentang materi Jujur, amanah, dan Istiqamah.

b. Menyusun lembar kerja siswa materi Jujur, amanah, dan Istiqamah.

b. Pelaksanaan Tindakan

Pada siklus I ini pembelajaran dilakukan dengan model Discovery Learning. Dengan model pembelajaran ini diharapkan para siswa lebih aktif dalam kegiatan pembelajaran terkait materi Jujur, Amanah, dan Istiqamah. Penggunaan model pembelajaran Discovery Learning pada siklus I ini bertujuan untuk meningkatkan keaktifan siswa karena memerlukan interaksi antar siswa dalam bentuk diskusi kelompok. Sehingga hasil belajar siswa pada materi Jujur, Amanah, dan Istiqamah dapat meningkat.

c. Hasil Pengamatan

Setelah proses pembelajaran peneliti kembali melakukan tes dengan tujuan untuk mengetahui keberhasilan proses pembelajaran. Adapun hasil pembelajaran tergambar dalam tabel berikut ini :

\begin{tabular}{|c|c|c|c|}
\hline $\begin{array}{c}\text { Indikator } \\
\text { Kemampuan }\end{array}$ & Rata-rata & $\begin{array}{c}\text { Persentase siswa } \\
\text { yang tuntas }\end{array}$ & $\begin{array}{c}\text { Persentase partisipasi } \\
\text { siswa dalam pembelajaran }\end{array}$ \\
\hline $\begin{array}{c}\text { Kemampuan } \\
\text { Pengetahuan }\end{array}$ & 78,78 & $68,75 \%$ & $46,86 \%$ \\
\hline KKM & 80 & 80 & \\
\hline
\end{tabular}

Tabel 2. Hasil penilaian dan pengamatan pada siklus I

Berdasarkan tabel 2 di atas, dapat dinyatakan bahwa partisipasi aktif siswa dalam mengikuti pembelajaran PAI kurang aktif (46,86\%). Kenaikan persentase partisipasi keaktifan siswa tersebut disebabkan faktor ketertarikan mereka terhadap model pembelajaran gaya baru. Namun bisa jadi ketertarikan itu sifatnya hanya temporer. Berdasarkan pengamatan peneliti, pada awalnya mereka begitu antusias, namun semakin lama para siswa tersebut merasa agak jenuh.

Pada saat dilakukan tes kemampuan pengetahuan tentang materi Jujur, Amanah, dan Istiqamah terdapat $68,75 \%$ siswa yang tuntas dan 31,25\% yang belum tuntas dan rata-rata nilainya 78,78 . Sementara hasil observasi dan wawancara menyatakan bahwa siswa tertarik dalam kegiatan pembelajaran yang dilakukan baru 46,86\%.

d. Refleksi

Setelah melakukan pengamatan pada tindakan siklus I, peneliti merasa bahwa model seperti tersebut memang berpengaruh dalam menarik perhatian siswa. Namun masih terdapat beberapa kelemahan sepanjang pengamatan peneliti. Kelemahan yang dimaksud antara lain : 
a. Perhatian siswa terhadap pembelajaran sifatnya hanya temporer. Semakin lama perhatian siswa semakin berkurang (tidak fokus).

b. Terdapat beberapa siswa yang tidak terfokus pada materi. Ada yang hanya ngobrol sendiri, dan ada pula yang usil dengan teman di depannya.

Kelemahan dalam siklus pertama ini membuat peneliti melakukan modifikasi lagi pembelajaran mendatang. Peneliti kemudian mengambil kesimpulan bahwa pada proses pembelajaran mendatang harus disertai multimedia yang relevan dan menarik perhatian siswa sehingga mereka dapat fokus pada materi pembelajaran.

\section{Deskripsi Tindakan Siklus II}

\section{Perencanaan Tindakan}

Pada tahap perencanaan peneliti melakukan beberapa kegiatan, yaitu:

a. Pembuatan RPP (lesson plan) tentang materi Jujur, Amanah, dan Istiqamah.

b. Menyusun lembar kerja siswa materi Jujur, Amanah, dan Istiqamah.

c. Menyiapkan multimedia pembelajaran yang digunakan pada materi Jujur, Amanah, dan Istiqamah, yaitu berupa powerpoint dan flipbook.

\section{Pelaksanaan Tindakan}

Pada siklus II ini pembelajaran dilakukan dengan model Discovery Learning berbantuan multimedia berupa LKS, powerpoint, dan flipbook. Dengan model pembelajaran ini diharapkan siswa lebih aktif dalam kegiatan pembelajaran terkait materi Jujur, Amanah, dan Istiqamah. Penggunaan model Discovery Learning berbantuan multimedia pada siklus II ini bertujuan untuk lebih meningkatkan keaktifan siswa karena memerlukan interaksi antar siswa dalam bentuk diskusi kelompok. Selain itu, multimedia yang digunakan pada siklus ini bertujuan untuk menarik perhatian siswa terhadap materi Jujur, Amanah, dan Istiqamah sehingga hasil belajar siswa dapat lebih meningkat.

3. Hasil Pengamatan

Setelah pembelajaran peneliti kembali melakukan tes formatif dengan tujuan untuk mengetahui tingkat keberhasilan proses pembelajaran tersebut. Adapun hasil pembelajaran tergambar dalam tabel berikut ini.

\begin{tabular}{|c|c|c|c|}
\hline $\begin{array}{c}\text { Indikator } \\
\text { Kemampuan }\end{array}$ & Rata-rata & $\begin{array}{c}\text { Persentase siswa } \\
\text { yang tuntas }\end{array}$ & $\begin{array}{c}\text { Persentase partisipasi siswa } \\
\text { dalam pembelajaran }\end{array}$ \\
\hline $\begin{array}{c}\text { Kemampuan } \\
\text { Pengetahuan }\end{array}$ & 84,91 & $87,5 \%$ & $84,38 \%$ \\
\hline KKM & 80 & 80 & \\
\hline
\end{tabular}

Tabel 3. Hasil penilaian dan pengamatan pada siklus II 
Berdasarkan tabel 3 di atas, dapat dinyatakan bahwa partisipasi keaktifan siswa dalam mengikuti pembelajaran PAI materi Jujur, Amanah, dan Istiqamah sampai pada level aktif (84,38\%). Kenaikan persentase partisipasi siswa tersebut disebabkan oleh faktor ketertarikan mereka ditambah adanya fokus perhatian yang lebih intens terhadap materi.

Pada saat dilaksanakan tes kemampuan pengetahuan tentang materi Jujur, Amanah, dan Istiqamah terdapat $87,5 \%$ siswa yang tuntas sehingga yang belum tuntas sejumlah $12,5 \%$. Sedangkan nilai rata-rata tes pengetahuan pada siklus II ini menjadi 84,91. Sementara hasil observasi dan wawancara menyatakan bahwa siswa tertarik dalam kegiatan pembelajaran yang dilakukan adalah sejumlah 84,38\% sehingga yang menyatakan kurang/tidak tertarik hanya 15,62\%.

4. Refleksi

Setelah melakukan pengamatan pada tindakan siklus II, peneliti berasumsi bahwa penggunaan model Discovery Learnimg dikolaborasikan dengan multimedia ternyata membawa dampak yang sangat signifikan. Berbeda dengan siklus I, pada siklus II ini sepertinya mereka ingin lebih fokus dalam menyimpulkan dan menyelesaikan lembar kerja. Kesempatan ini digunakan untuk bertanya kepada guru maupun teman. Disamping itu, adanya multimedia dalam pembelajaran di siklus II ini siswa berpartisipasi aktif baik perhatian, penglihatan, pendengaran, maupun aktivitas fisiknya (gerakan).

\section{Pembahasan Tiap Siklus dan Antarsiklus}

Berdasarkan uraian pembahasan pada siklus I dan siklus II maka hasil dari tindakan yang dilakukan peneliti dapat digambarkan dalam tabel berikut.

\begin{tabular}{|c|c|c|c|c|c|c|c|c|c|}
\hline \multirow{2}{*}{$\begin{array}{c}\text { Indikator } \\
\text { Kemampuan }\end{array}$} & \multicolumn{3}{|c|}{$\begin{array}{c}\text { Rata-rata hasil } \\
\text { penilaian }\end{array}$} & \multicolumn{3}{c|}{$\begin{array}{c}\text { Persentase siswa } \\
\text { yang tuntas (\%) }\end{array}$} & \multicolumn{3}{c|}{$\begin{array}{c}\text { Persentase partisipasi } \\
\text { aktif siswa (\%) }\end{array}$} \\
\cline { 2 - 10 } & KA & I & II & KA & I & II & KA & I & II \\
\hline $\begin{array}{c}\text { Kemampuan } \\
\text { Pengetahuan }\end{array}$ & 72,31 & 78,78 & 84,91 & 37,5 & 68,75 & 87,5 & 40,63 & 46,86 & 84,38 \\
\hline KKM & 80 & 80 & 80 & 80 & 80 & 80 & & & \\
\hline
\end{tabular}

Tabel 4 : Hasil penilaian dan pengamatan pada tiap siklus

Ket : KA = Kondisi Awal, I = Siklus I, II = Siklus II

Grafik peningkatan nilai rata-rata hasil belajar siswa kelas VII.3 SMP Negeri 2

Rembang dalam materi Jujur, Amanah, dan Istiqamah adalah: 


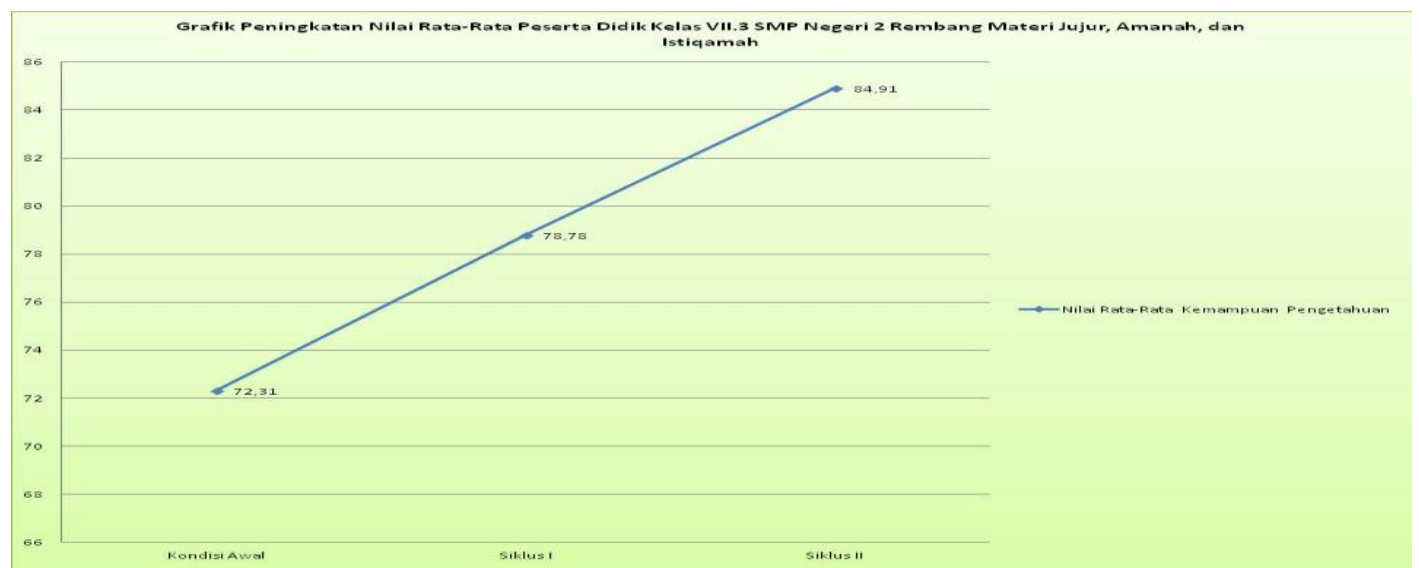

Sedangkan grafik peningkatan persentase ketuntasan siswa kelas VII.3 SMP Negeri 2 Rembang dalam materi Jujur, Amanah, dan Istiqamah adalah:

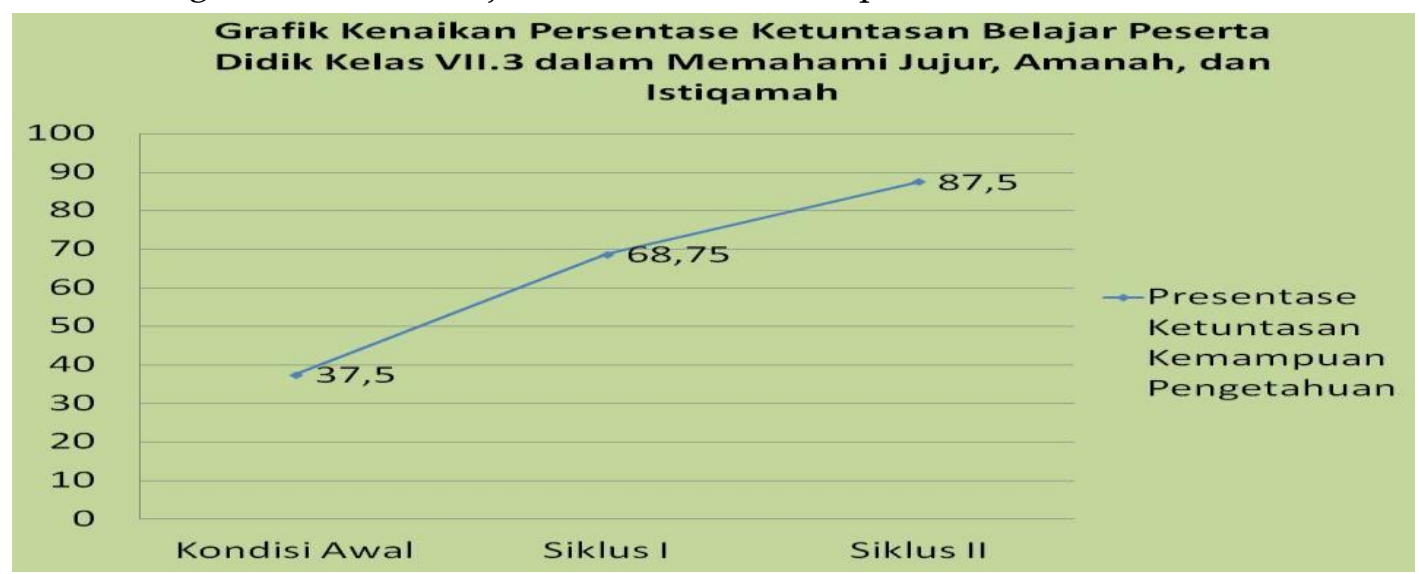

Berikutnya grafik peningkatan persentase keaktifan siswa kelas VII.3 SMP Negeri 2 Rembang dalam materi Jujur, Amanah, dan Istiqamah.

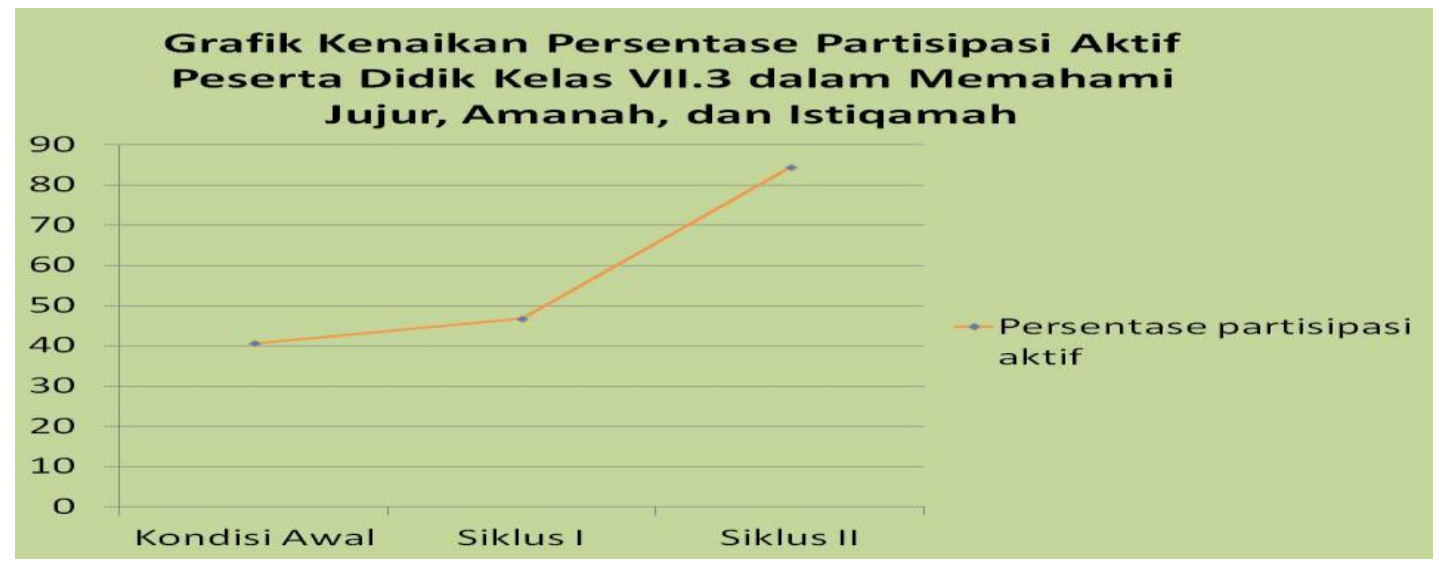

Grafik 3. Kenaikan Persentase Ketuntasan Belajar dalam Memahami Materi Jujur, Amanah, dan Istiqamah

Berdasarkan Tabel 4 terlihat bahwa partisipasi siswa dalam mengikuti pembelajaran PAI materi Jujur, Amanah, dan Istiqamah sebelum adanya tindakan sangat rendah, yaitu nilai rata-ratanya 72,31 dan tingkat ketuntasannya hanya 37,5\% sedangkan 
FITRAH Vol.01 No. 2 Juli-Desember 2015

partisipasi aktif siswa dalam kegiatan pembelajaran pra siklus ini baru mencapai 40,63\%. Rendahnya hasil tersebut dikarenakan siswa kurang tertarik dengan pembelajaran yang dilakukan. Mereka cenderung bosan dan jenuh dengan materi pembelajaran tersebut.

Hasil belajar yang demikian membuat peneliti berusaha untuk mencari solusi agar pembelajaran lebih menarik dan mampu memancing perhatian siswa. Peneliti mempunyai ide untuk menyajikan dengan model Discovery Learning.

Setelah dilakukan tindakan pada siklus I, partisipasi aktif siswa dalam mengikuti pembelajaran PAI ternyata masih kurang aktif, yaitu mencapai 46,86\%. Kenaikan persentase partisipasi keaktifan siswa tersebut disebabkan faktor ketertarikan mereka terhadap model pembelajaran gaya baru. Namun demikian, bisa jadi ketertarikan itu sifatnya hanya temporer. Berdasarkan pengamatan peneliti, pada awalnya mereka begitu antusias, namun semakin lama para siswa tersebut merasa agak jenuh. Walaupun demikian, meningkatnya perhatian siswa pada siklus I ini telah berhasil menaikkan hasil belajar.

Pada saat dilakukan tes kemampuan pengetahuan pada siklus I tentang materi Jujur, Amanah, dan Istiqamah terdapat 68,75\% siswa yang tuntas dan 31,25\% yang belum tuntas dan rata-rata nilainya 78,78. Sementara hasil observasi dan wawancara menyatakan bahwa siswa tertarik dalam kegiatan pembelajaran yang dilakukan baru $46,86 \%$.

Hal ini menggambarkan bahwa telah terjadi peningkatan hasil tes kemampuan pengetahuan siswa pada materi Jujur, Amanah, dan Istiqamah dari kondisi awal yang hanya mencapai rata-rata 72,31 menjadi 78,78 pada siklus I. Sedangkan ketuntasannya naik dari $37,5 \%$ pada kondisi awal menjadi $68,75 \%$ pada siklus I. Sehingga peningkatan nilai rata-ratanya sebesar 6,47 sedangkan persentase ketuntasannya naik sebesar 21,25\%.

Setelah dilakukan tindakan pada siklus II, partisipasi keaktifan siswa dalam mengikuti pembelajaran PAI materi Jujur, Amanah, dan Istiqamah sampai pada level $84,38 \%$. Kenaikan persentase partisipasi siswa tersebut disebabkan oleh faktor ketertarikan mereka pada kegiatan pembelajaran semakin bertambah sehingga fokus dan perhatian mereka lebih intens terhadap materi pembelajaran.

Pada saat dilakukan tes kemampuan pengetahuan pada siklus II tentang materi Jujur, Amanah, dan Istiqamah terdapat $87,5 \%$ siswa yang tuntas sehingga yang belum tuntas sejumlah $12,5 \%$. Sedangkan nilai rata-rata tes pengetahuan pada siklus II ini menjadi 84,91. Sementara hasil observasi dan wawancara menyatakan bahwa siswa tertarik dalam kegiatan pembelajaran yang dilakukan adalah sejumlah 84,38\% sehingga yang menyatakan kurang/tidak tertarik hanya $15,62 \%$.

Hal ini menggambarkan bahwa telah terjadi peningkatan hasil tes kemampuan pengetahuan siswa pada materi Jujur, Amanah, dan Istiqamah dari siklus I ke siklus II. 
Peningkatan ini berupa peningkatan nilai rata-rata tes kemampuan pengetahuan 78,78 pada siklus I menjadi 84,91 pada siklus II. Sedangkan ketuntasannya naik dari $68,75 \%$ pada siklus I menjadi $87,5 \%$ pada siklus II. Sehingga peningkatan nilai rata-ratanya dari siklus I ke siklus II sebesar 6,13 sedangkan persentase ketuntasannya naik sebesar 18,75\%.

\section{PENUTUP}

Sesuai dengan hasil penelitian ini, dapat disimpulkan bahwa penerapan model pembelajaran berbasis saintifik berbantuan multimedia dapat meningkatkan hasil belajar siswa kelas VII.3 SMP Negeri 2 Rembang pada materi jujur, amanah, dan istiqamah, yaitu dari kondisi awal rata-rata kemampuan pengetahuannya 72,31 menjadi 78,78 pada siklus I dan meningkat lagi menjadi 84,91 pada siklus II. Sedangkan persentase ketuntasan siswa meningkat dari kondisi awal $37,5 \%$ menjadi $68,75 \%$ pada siklus I dan meningkat lagi menjadi $87,5 \%$ pada siklus II.

Motivasi belajar siswa kelas VII.3 SMP Negeri 2 Rembang pada materi jujur, amanah, dan istiqamah dengan penerapan model pembelajaran berbasis saintifik berbantuan multimedia mengalami peningkatan. Hal ini terlihat dari persentase partisipasi aktif siswa pada kondisi awal 40,63\% menjadi $46,86 \%$ pada siklus I dan meningkat lagi menjadi $84,38 \%$ pada siklus II. 
FITRAH Vol.01 No. 2 Juli-Desember 2015

\section{DAFTAR PUSTAKA}

Achmadi, Ideologi Pendidikan Islam: Paradigma Humanisme Teosentris. Yogyakarta: Pustaka Pelajar, 2005.

Dekonstruksi Pendidikan Islam Sebagai Subsistem Pendidikan Nasional, dalam Guru Besar Bicara: Mengembangkan Keilmuan Pendidikan Islam. Semarang: RaSAIL Media Group, 2010.

Asri Budiningsih, Belajar dan Pembelajaran. Jakarta: Rineka Cipta, 2004.

Departemen Agama RI, Syaamil Al-Quran: Al-Qur'an Terjemah Per Kata. Jakarta: Sygma, 2009

Hamalik Oemar, Psikologi Belajar Mengajar. Bandung: Sinar Baru Algensindo, 1992

Hamruni, Strategi dan Model-Model Pembelajaran Aktif Menyenangkan. Yogyakarta: Fakultas Tarbiyah UIN Sunan Kalijaga, 2009.

Lexy Moleong, Metodologi Penelitian Kualitatif. Bandung: Remaja Rosdakarya, 2000.

Muhibbin Syah,. Psikologi Belajar. Bandung: Remaja Rosdakarya, 2007

Nana Sudjana, Cara Belajar Siswa Aktif Dalam Belajar Mengajar. Bandung: Sinar Baru, 2000.

Ngalim Purwanto, Psikologi Pendidikan. Bandung: Remaja Rosdakarya, 2002.

Nurhadi, Pembelajaran Kontekstual. Malang: Universitas Negeri Malang, 2004.

Sadiman, dkk, Media Pendidikan. Bandung: Raja Grafindo Persada, 2003.

Slavin, R.E. 2005. Cooperative Learning: Teori, Riset, dan Praktik. Diterjemahkan oleh Nurulita. Bandung: Nusa Media, 2008.

Sumadi Suryabrata, Psikologi Pendidikan. Jakarta: RajaGrafindo Persada, 2002

Suprayekti. Interaksi Belajar Mengajar. Jakarta: Depdiknas, 2003

Syaiful Bahri Djamarah, Guru dan Siswa dalam Interaksi Edukatif. Jakarta: PT. Rineka Cipta, 2000.

Undang-Undang No. 20 Tahun 2003 tentang Sistem Pendidikan Nasional.

Usman, dkk., Upaya Optimalisasi kegiatan Belajar Mengajar. Bandung: Remaja Rosdakarya, 1993.

Wina Sanjaya, Strategi Pembelajaran Berorientasi Standar Proses Pendidikan. Jakarta: Kencana, 2008. 